\section{Scientific Appointments at the Ministry of Supply}

Sir Ben LockSPEISE, director-general of scientific research (air) at the Ministry of Supply, has been appointed clef scientist to.the Ministry. This newly created post is a continuation of the co-ordination of the rescarch and development programmes for defenge and air resulting from the merger earlier this year of the Ministry of Supply and the Ministry of Aircraft Production. Sir Ben will be responsible in future for co-ordinating research work on the Ministry's military and aeronautical programmes, and for supervising the general interests and welfare of its large scientific staff. $\mathrm{He}$ will be assisted in these duties by the Scientific Co-ordinating Board, to which Sir John Lennard-Jones has agreed to continue to act as chairman for the present. The Ministry has also announced that the following four appointments, all at Principal Director level, will be incorporated in its higher organisation for research and development : Scientific Research (Air) : Mr. H. M. Garner, who has held a number of posts in the scientific departments of the Air Ministry, Ministry of Aircraft Production and Ministry of Supply since his entry into Government service soon after the First World War; between 1942 and 1945 he was deputy director of scientific research in the Ministry of Aircraft Production. Technical Development (Defence): Mr. T. R. B. Sanders, who served with the Royal Artillory in the early part of the War, later becoming assistant chief engineer of armaments design in the Ministry of Supply, Scientific Research (Defence): Dr. E. T. Paris, who joined the Ministry of Supply upon its formation in 1939, previously having been deputy director of scientific research at the War Office; prior to taking up his present appointment he was controller of physical and signal development in the Ministry of Supply, being responsible (under the Director-General of Scientific Research and Development) for all Army signals and radar development. Technical Development (Air) : Mr. S. Scott-Hall, who from 1944 until taking up his present post was superintendent of performance testing at the Aeroplane and Armaments Experimental Establishment, Boscombe Down, Wiltshire; between 1941 and 1944 he was head of the Armament Research and Development Department of the Royal Aircraft Establish ment, Farnborough.

The Ministry of Supply further announces that responsibility for all branches of research and development concerning guided projectiles-including the proposed range in Australia - are to be integrated under the Controller of Supplies (Air). Details of the new organisation will be given in due course.

\section{National Coal Board: Director of Carbonization Research}

THE National Coal Board announces that Prof. H. L. Riley, professor of inorganic and physical chemistry in the University of Durham, has been appointed/director of carbonization research under the scightific member of the Board, Sir Charles Ellis. Prof Riley studied at the Imperial College of Science and Technology, and took an honours degree in inorganic chemistry; he was awarded the Frank Haddon Prize. He held a Beit Research Fellowship during 1921-23, and remained as lecturer at the Imperial College until he went in 1932 to King's College, University of Durham. Prof. Riley's research work at Newcastle has been devoted to the study of coking problems, and he is recognized as an expert in this field. $\mathrm{He}$ is also honorary secretary and director of research to the Northern Coke Research Committee, and is a member of the British Coking Research Association. $\mathrm{He}$ is forty-seven years of age.

\section{Chemistry at Chelsea Polytechnic: Dr. J. F. J. Dippy}

When Dr. C. Doree retired from the post of head of the Depaydment of Chemistry at the Chelsea Polytechnic/n 1940, the vacancy was filled by the promotion of Dr. J. C. Crocker, then first assistant in the Department; Dr. Crocker retired at the end of Aagust. Dr. John F. J. Dippy has now been appointed to the post. Educated at University College, Swansea, Dr. Dippy showed early promise as a research worker, and his work has been well recognized in Great Britain and in the United States. $\mathrm{H}_{\theta}$ is an energetic man with interests in both pure and applied chemistry. Beginning with a lectureship in chemistry at the Cardiff Technical College (1930), Dr. Dippy moved to a headship at the Mining and Technical College, Wigan (1942), and is at present head of the Department of Chemistry and Biology at the South-East Essex Technical College, Dagenham (since 1945). He has high academic and administrative ability.

\section{Agricultural Attaché at the British Embassy in Buenos Ayres}

MaJor T.A. RATTRAY has been appointed agricultural gtaché to the British Embassy in Buenos Ayres. Major Rattray, who is fifty-seven, was educated at Winchester. After service in the First World War, he farmed in Shropshire and Somerset until, in 1934, he took up an appointment with the Ministry of Agriculture as a livestock officer. From 1939 onwards Major Rattray has acted as one of the Ministry's land commissioners.

\section{Reports on German Industrial and Scientific Pro- gress}

IN a written answer to a question regarding reports on German inplystrial and scientific progress on December 5, th President of the Board of Trade stated the, 90 such reports have been published to A te, 52 by British teams, 278 by American teams and $\$ 40$ by combined teams, and it is expected that thd fotal would approach 2,500 . In addition to placing the reports on sale at H.M. Stationery Office, free distributions of all reports published are made to universities, the principal public libraries and chambers of commerce. Trade and research associations and learned professional institutions also receive a token free distribution of the reports of direct interest to them. Arrangements have been made with the Stationery Office to produce both a classified list of the reports and a subject index, and an Information Bureau and Reference Library has also been created at the secretariat of the British Intelligence Objectives Sub-Committee, which body is now administered by the Board of Trade. This Reference Library contains not only all the finished reports but also much of the raw material on which they were based. The work is closely co-ordinated with the Documents Unit of the Board of Trade, which is the central repository for the large quantity of original German documents collected in the British and allied investigations. The Unit has facilities for translating and abstracting and. 